\title{
IMPACT OF OCCUPANCY IN COLLECTIVE ACCOMMODATION ESTABLISHMENTS IN THE CZECH REPUBLIC ON THE SELECTED MACROECONOMIC VARIABLES IN THE YEARS 2001 - 2015
}

\author{
[Vliv návštěvnosti v hromadných ubytovacích zařízeních v ČR na vybrané \\ makroekonomické proměnné v letech 2001 - 2015] \\ Patrik Kajzar $^{1}$, Klára Václavínková $^{2}$ \\ ${ }^{\text {I}}$ Silesian University, School of Business Administration, Univerzitní nám. 1934/3,733 40 Karviná \\ Email:kajzar@opf.slu.cz \\ ${ }^{2}$ Silesian University, School of Business Administration, Univerzitni nám. 1934/3,733 40 Karviná \\ Email:vaclavinkova@opf.slu.cz
}

\begin{abstract}
The aim of this paper is to assess the impact of occupancy in collective accommodation establishments in the Czech Republic at an average rate of unemployment (\%) to GDP (\%) and the average pace of real wage growth (\%) between 2001-2015. The methods are regression and correlation analysis. The output is then to evaluate the impact of occupancy on the selected parameters. The most significant impact in collective accommodation establishments can be observed in occupancy at the average rate of unemployment. When we are comparing the GDP growth parameters and occupancy collective accommodation establishments there is no evidence of a linear relationship.
\end{abstract}

Keywords: collective accommodation establishments, correlation analysis, the Czech Republic, macroeconomic variables, occupancy, regression.

JEL classification: C02, L83

Doručeno redakci: 14.12.2016; Recenzováno: 12.1.2017; 13.1.2017; Schváleno k publikování: 1.3.2017

\section{Introduction}

Tourism is one of the fundamental factors for strengthening the economy in the Czech Republic. Tourism can be seen in the arrival or departure of visitors. The authors focus on some of the indicators that have an impact on the visitor accommodation. The following text is devoted to guests in collective accommodation establishments between the years 2001 to 2015. The authors focused on specific variables and an average unemployment rate (\%) to GDP (\%), and the average pace of the real wage growth (\%) between 2001-2015. The authors use data of tourist collective accommodation establishments. These data include the data from the Czech Statistical Office.

The authors divide the article into 4 chapters. The first chapter is devoted to theoretical bases of examined issues. The second chapter deals with the development of occupancy in collective accommodation establishments in the Czech Republic between 2001- 2015 and it includes current data for the first half of 2016. In the third chapter, the authors pay attention to the mathematical definition of regression and correlation analysis, which is used to describe the statistical dependencies. The fourth and last chapters have been devoted to the analysis of selected economic indicators, including their evaluation.

The Quality statistical information is important for the effective development of tourism. At present, this information is missing and for this reason the authors focused on working with the average rate of unemployment $(\%)$ to GDP $(\%)$ and the average pace of the real wage 
growth (\%) between 2001-2015. The relevant information is also presented by economic data, in particular the share of tourism in the gross domestic product (GDP). The overlaps of tourism to other sectors makes necessary to use a method generating indicators, as experts estimate. New periodic or one-time special statistical surveys are carried out for this purpose. The Project of the National Tourism Satellite Account is realized for this purpose. It has been existing since 1999. The explanatory power of tourism statistics in particular since 2006 has greatly improved and can be evaluated in comparison with other countries as very good. More detailed information is absent at the regional level for domestic users. Authors try to find a link between attendance and the average rate of unemployment (\%) to GDP (\%) and the average pace of the real wage growth (\%) between 2001-2015.

The significance of tourism statistics consists in its necessity for planning marketing strategies, evaluating the effectiveness of selected decisions and measuring tourism in all areas of the national economy. The results of the research are intended for readers of segment experts in tourism and show the importance of influence occupancy in collective accommodation establishments in the Czech Republic at an average rate of unemployment $(\%)$ to GDP (\%) and the average pace of the real wage growth (\%). It is a period between 2001-2015. The authors also see the use of the results in practical application in tourism businesses.

\section{Theoretical resources examined issues}

The tourism industry (or sector) is an important activity that represents not only a large component of a national economy but also an important force in the world economy. Despite tourism's considerable importance in the production of services and intangible assets, its economic contribution is very difficult to quantify. Indeed, unlike the other economic sectors, tourism is not incorporated into the national account structure because it cannot be reduced to a single sector. Tourism does not produce a specific and easily identifiable goods, but rather a combination of heterogeneous items from different sectors which all together constitute a set of goods and services generally called 'tourism product (Lamonica and Mattioli 2015).

The tourism sphere that covers accommodation services in the European Union countries is currently one of the most watched (significant) priorities of national economies. The border opening, free movement of goods and labour mean an increase of pressure on the European market, which itself represents a highly competitive environment. Limiting factors of tourism development are only some limits of foreign exchange and visa requirements concerning certain countries. For accurate understanding and evaluation of the contribution of tourism it is essential to measure and monitor its achievements and performance indicators (Šambronská, Matušíková, Šenková and Mitríková 2016).

According to Morrison (1995) the typical characteristics of tourism marketing can be divided into generally applicable and relevant specifics.

Tourism services form several categories. They are representing the main service essential activities such as transport, catering, and guide services, which includes a guide, an interpreter and a program creation for leisure. Another group are complementary services such as informatics, promotion and advertising, and the last service infrastructure including transportation network, business network or a system of health care (Václavínková 2012).

Morrison (1995) has defined six general specifics that affect marketing services and cannot be changed or deleted: 
- Services are intangible in nature.

- Production services are often inseparable from their place of consumption

- Services cannot be stored. If they are not sold at the time they are offered, they cannot be sold later and simply do not longer exist.

- Costs are subject to variability and the intangible services provided

- Some services cannot be separated from individuals who provide them. An example might be seen in hotels, restaurants and spa facilities.

It should be noted that services are not homogenous and the creation of menus does not always follow the same factors. The wide range of new services in market characteristics play a major role as the degree of tangibility, the extent of direct contact with the customer, technology and equipment used in the production of services (Jakubíková 2012).

Marketing activities in many tourism businesses have a very specific character. Marketing functions in them are often limited to supporting the implementation of services (e.g. advertising, sales promotion, etc.), (Jasinskas et al. 2016).

There is also seen a considerable influence of government regulation and deregulation in the field of tourism. Moreover, in this area they play a key role in supporting government agencies and non-profit organizations that promote the site and often have different objectives from business entities. Tourism and multiplication effect in the region's contribution deal with the issue of tourism, its position and economic consequences (Pellesova 2015).

Great importance is placed on word-of-mouth advertising. Most services cannot be a pretest, because customers rely on when choosing other people's experiences, which is also related to an increased need for support materials (Kostková, Lukoszová and Wilczková 2009).

Tourism in countries with a high number of tourist arrivals positively affects the balance of payments in the country, the state budget revenues at the local level improves local budgets, and supports the investment activity in the regions (Vágner 2011).

The economic explanation is provided in terms of both demand and supply. The demand profile and motivations are different in two kinds of destinations. Hotel specialised destinations depend primarily on holiday markets while residential destinations depend on other elements affecting investment alternatives (buying a second home is usually seen as an investment), such as interest rates and credit facilities. Policy-makers can gain valuable insight from this study regarding the prevention of the negative effects of the economic crisis in destinations. First, city destinations should be as diversified as possible. Second, regional authorities could promote their tourism using an appropriate combination of the two kinds of destinations to better withstand the economic crisis that could asymmetrically affect both types of destinations, as it was in the case of the most recent economic crisis. Finally, proactive employment policy resources should mainly focus on residential destinations, the worst affected by the crisis. These actions would help to avoid job losses during the crisis times, which become irreversible during the growth periods (Perles-Ribes et al 2016).

\section{Occupancy in collective accommodation establishments in the Czech Republic between 2001 - 2015}

Occupancy in the years 2001-2015 had a fluctuating character. The authors Ram and Ural (2016) said that the study seemed important for judging how data on this crucial variable from two most widely used sources agree or differ. The reported huge differences suggest that the 
users may exercise caution in drawing strong conclusions from information derived from either source, and may consider doing some sensitivity checks based on data from the other source. The presented chart assesses the evolution of guests at collective accommodation establishments in the following parameters: total number of guests, number of nonresidents, and number of residents. We can say that the number of guests has been increasing since 2002. The exceptions are the years 2008 to 2011. The reason is the ongoing global economic crisis. In 2015, there was the largest number of guests. For other parameters, there is a similar trend. We can see the total number of guests 11283185 in 2001, including 5405239 nonresidents and 5877946 residents. There was an increase in the following years from 10415255 total number of guests in 2002 to the number of 12960921 in 2007 and 2008, when the total number of guests was 12835886 . The increase also occurred in 2013 when the total number was 13868336 . In the year 2008 there were 6649410 nonresidents and 6186476 residents. The number of nonresidents was 6186476 in 2008 and the number of residents 6558480 in 2013. The total number of guests was 15587076 in 2014 and in 2015 there was an increase to 17195550 .

Figure 1: Occupancy in collective accommodation establishments in the Czech Republic between $2001-2015$

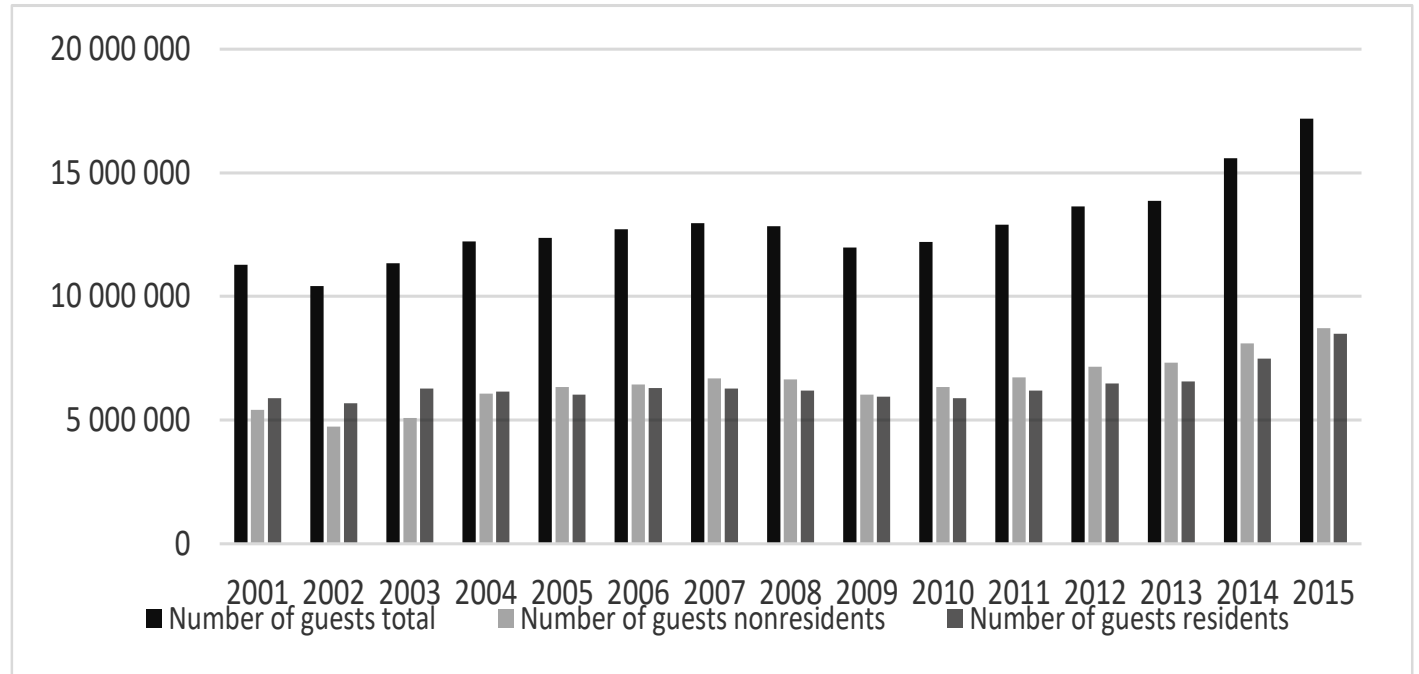

Source: Own elaboration based on web portal Czech Statistical Office: Cestovní ruch - časové rady. [online][vid. 29. září 2016]. Dostupné z: https://www.czso.cz/csu/czso/cru_cr

Occupancy in collective accommodation establishments in the first half of 2016.

At the time when the article was created, the data from the first half of 2016 were published. For the sake of completeness, the authors present these data.

In the 2nd quarter in 2016 the total number of guests in collective accommodation establishments in the county rose from the first quarter by almost $40 \%$, more than 48,000 people. An annual increase reached $1.6 \%$, which is the fourth lowest growth among the regions. Domestic guests accounted for the overwhelming majority, the foreign visitors accounted for about $16 \%$ of the total. The number of overnight stays amounted to 514.6 thousand and in comparison with the same period of 2015 increased by $2.8 \%$. In the period from the beginning of the year to the end of June 2016 total of 301,000 guests visited and stayed overnight at least one night in collective accommodation establishments in the Zlin region. The number of guests - resident (foreign) increased by $15.5 \%$, domestic guests (residents) increased by $1.7 \%$. The growth was recorded in overnight stays in both groups of 
visitors at home by $4.3 \%$ and non-residents by $8.2 \%$. The total number of overnight stays by non-residents increased compared to the 1 st half of 2015 by $8.2 \%{ }^{1}$

\section{$3 \quad$ Material and Methods}

This aim of the paper is to assess the impact of occupancy in collective accommodation establishments in the Czech Republic at an average rate of unemployment (\%) to GDP (\%) and the average pace of the real wage growth (\%) between 2001-2015.

The data on accommodation establishments come from the List of collective accommodation establishments and the survey on capacity and guests in collective accommodation establishments.

In the following paper the authors pay attention to the mathematical definition of the regression and correlation analyses which are used to describe the statistical dependencies.

Hindls, Hronová, Seger and Fischer (2007), McClave and Sincich (2011), Ramík and Stoklasová (2013), Tošenovský (2014) say that the regression analysis is concerned with unilateral dependencies, this means that it examines general trends in changes in response variables (the dependent variable y) due to changes in explanatory variables (independent variable $\mathrm{x}$ ). The correlation analysis focuses on the interdependencies.

To determine the tightness of dependence (relative strength) of two variables the correlation analysis will be used. Determining extent of dependence or correlation we use the correlation coefficient. The coefficient values between -1 and +1 , where -1 means a perfect negative, +1 , and perfect positive relationship and 0 mean no linear relationship.

It describes in addition to strength its direction depending addiction.

First we calculate the correlation coefficient. The procedure is that:

$\mathrm{r}=\operatorname{Cov}(\mathrm{X}, \mathrm{Y}) / \sqrt{ } \operatorname{Var}(\mathrm{X}) \operatorname{Var}(\mathrm{Y})$

Where:

$\operatorname{Cov}(\mathrm{y}, \mathrm{x})=$ the covariance of $\mathrm{y}$ and $\mathrm{x}$

$\operatorname{Var}(\mathrm{x})=$ the variance of $\mathrm{x}$

$\operatorname{Var}(\mathrm{y})=$ the variance of $\mathrm{y}$

Covariance provides a measure of the strength of the correlation between two or more sets of random variates. The covariance for two random variates $X_{\text {and }} Y$, each with sample size $N$, is defined by the expectation value

$\begin{array}{rlll}\operatorname{cov}(X, Y) & = & \left\langle\left(X-\mu_{X}\right)\left(Y-\mu_{Y}\right)\right\rangle \\ & = & \langle X Y\rangle-\mu_{X} \mu_{y}\end{array}$

where $\mu_{x}=\langle X\rangle_{\text {and }} \mu_{y}=\langle Y\rangle_{\text {are }}$ the respective means, which can be written out explicitly as

\footnotetext{
${ }^{1}$ Web portal of the Czech Statistical Office: The main macroeconomic indicators. [Online] [vid. September 29, 2016]. Available from: https://www.czso.cz/csu/czso/hmu_cr
} 


$$
\operatorname{cov}(X, Y)=\sum_{i=1}^{N} \frac{\left(x_{i}-\bar{x}\right)\left(y_{i}-\bar{y}\right)}{N} .
$$

For uncorrelated variates,

$$
\operatorname{cov}(X, Y)=\langle X Y\rangle-\mu_{X} \mu_{Y}=\langle X\rangle\langle Y\rangle-\mu_{X} \mu_{Y}=0,
$$

so the covariance is zero. However, if the variables are correlated in some way, then their covariance will be nonzero. In fact, if $\operatorname{cov}(\mathrm{X}, \mathrm{Y})>0$, then $\mathrm{Y}$ tends to increase as $\mathrm{X}$ increases, and if $\operatorname{cov}(\mathrm{X}, \mathrm{Y})<0$, then $\mathrm{Y}$ tends to decrease as $\mathrm{X}$ increases.

The variance is a measure of how spread out the values of $\mathrm{X}$ would be if the experiment leading to $\mathrm{X}$ were repeated a number of times.

The variance of $\mathrm{X}$, written as $\operatorname{Var}(\mathrm{X})$ is given by:

$\operatorname{Var}(X)=E\left(X^{2}\right)-(E(X))^{2}$

If we write $\mathrm{E}(\mathrm{X})=\mu$ then:

$\operatorname{Var}(X)=E\left(X^{2}\right)-\mu^{2}$

The variance of $\mathrm{Y}$, written as $\operatorname{Var}(\mathrm{Y})$ is given by:

$\operatorname{Var}(\mathrm{Y})=\mathrm{E}\left(\mathrm{Y}^{2}\right)-(\mathrm{E}(\mathrm{Y}))^{2}$

If we write $\mathrm{E}(\mathrm{Y})=\mu$ then:

$\operatorname{Var}(\mathrm{Y})=\mathrm{E}\left(\mathrm{Y}^{2}\right)-\mu^{2}$

Then authors use a regression analysis. The regression analysis deals with dependence of a quantitative variable on one or more quantitative variables. In the case of one variable depending on another variable, we talk about simple regression, as opposed to the case when there are more explanatory variables. The regression analysis aims to find a mathematical relation - an equation which in a certain sense describes changes of a random variable $\mathrm{Y}$ dependent on changes of random variables X1, X2, .., Xk. We shall assume the standard case presented in literature, i.e. the case when only some values of the variables $\mathrm{X} 1, \mathrm{X} 2, \ldots, \mathrm{Xk}$ are known or available.

The objective of regression is to estimate the unknown parameters. The regression equation simply describes the relationship between the dependent variable (y) and the independent variable (x).The intercept, or "a", is the value of $y$ (dependent variable) if the value of $x$ (independent variable) is zero.

The parameters of the regression line:

$$
\begin{aligned}
& b=\operatorname{cov} / v a r x \\
& a=\varnothing y-b \cdot \varnothing x
\end{aligned}
$$


The regression equation:

$\mathrm{y}=\mathrm{a}+\mathrm{b} \cdot \mathrm{x}(2001)$

$\mathrm{y}=\mathrm{a}+\mathrm{b} \cdot \mathrm{x}(2015)$

\section{$4 \quad$ Results and Discussion}

The following lines are devoted to the analysis of selected economic indicators. It is the development of selected macroeconomic indicators in the years 2001 to 2015. These indicators are the average unemployment rate, the GDP and the average growth rate of real wages.

Figure 2: Development of selected economic indicators in the Czech Republic between $2001-2015$

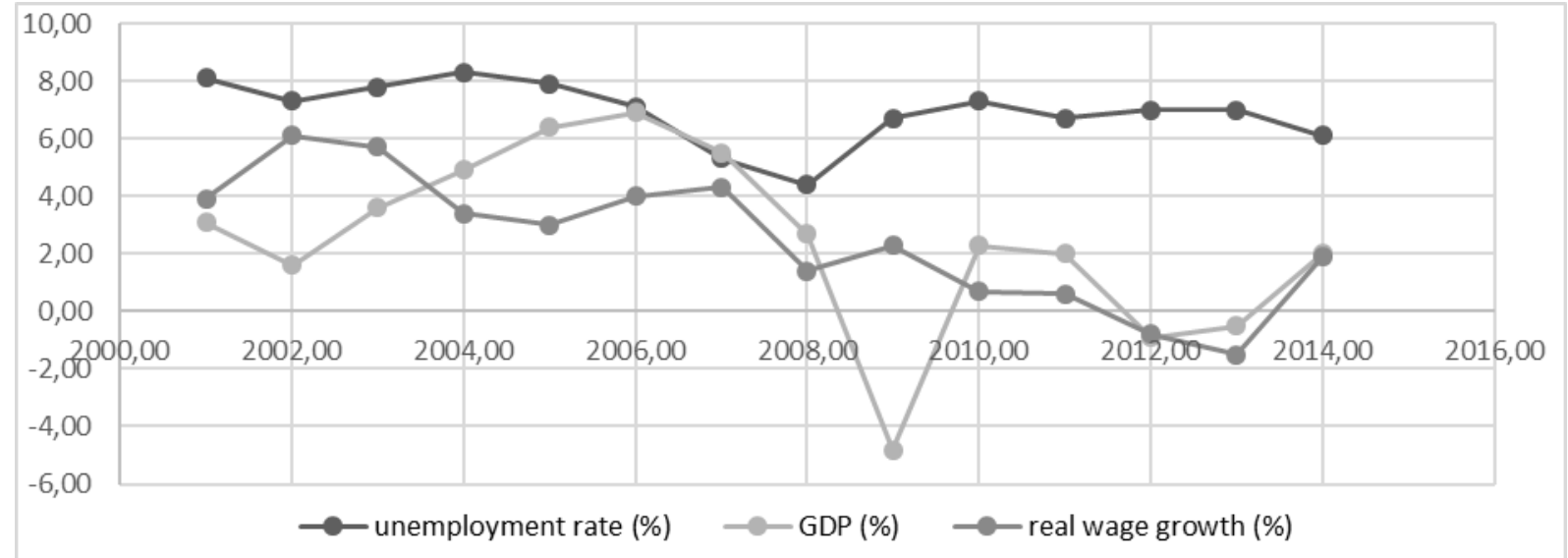

Source: Own elaboration based web portal Czech Statistical Office: Hlavní makroekonomické ukazatele. [online][vid. 29. záŕí 2016]. Dostupné z: https://www.czso.cz/csu/czso/hmu_cr

The second figure shows the evolution of the average unemployment rate, GDP and the average growth rate of real wages. This is the data from the years 2001 to 2015 . The chart illustrates that in 2009 there was a significant decline in the GDP, which could be the result of the ongoing global economic crisis. The average growth rate of real wages declined from 2001 to 2013. The average unemployment rate remains at similar levels, a significant decrease was only in 2008.

In this part of the paper the authors compiled Correlation Table 1, which shows the development of values occupancy of accommodation facilities related to the average unemployment rate $(\%)$ and calculated the parameters required for the calculation of correlation. The authors investigated the dependence of the average unemployment rate $(\%)$ and the overall attendance at collective accommodation establishments in the Czech Republic during the period $2001-2015$. 
Table 1: Dependence of the average unemployment rate (\%) in total attendance at collective accommodation establishments in the Czech Republic during the period 2001-2015

\begin{tabular}{|c|c|c|c|c|c|}
\hline Year & $\begin{array}{l}\text { (xi) } \\
\text { Number of guests } \\
\text { total }\end{array}$ & $\begin{array}{l}\left(\mathbf{y}_{\mathbf{i}}\right) \\
\text { unemployment } \\
(\%)\end{array}$ & $\mathbf{X i} * \mathbf{Y i}$ & $\mathrm{Xi2}$ & Yi2 \\
\hline 2001 & 11283185 & 8,1 & 91393798,5 & 127310263744225 & 65,61 \\
\hline 2002 & 10415255 & 7,3 & 76031361,5 & 108477536715025 & 53,29 \\
\hline 2003 & 11346482 & 7,8 & 88502559,6 & 128742653776324 & 60,84 \\
\hline 2004 & 12219689 & 8,3 & 101423418,7 & 149320799256721 & 68,89 \\
\hline 2005 & 12361793 & 7,9 & 97658164,7 & 152813926174849 & 62,41 \\
\hline 2006 & 12724926 & 7,1 & 90346974,6 & 161923741705476 & 50,41 \\
\hline 2007 & 12960921 & 5,3 & 68692881,3 & 167985473168241 & 28,09 \\
\hline 2008 & 12835886 & 4,4 & 56477898,4 & 164759969404996 & 19,36 \\
\hline 2009 & 11985909 & 6,7 & 80305590,3 & 143662014556281 & 44,89 \\
\hline 2010 & 12211878 & 7,3 & 89146709,4 & 149129964286884 & 53,29 \\
\hline 2011 & 12898712 & 6,7 & 86421370,4 & 166376771258944 & 44,89 \\
\hline 2012 & 13646913 & 7 & 95528391 & 186238234429569 & 49 \\
\hline 2013 & 13868336 & 7 & 97078352 & 192330743408896 & 49 \\
\hline 2014 & 15587076 & 6,1 & 95081163,6 & 242956938229776 & 37,21 \\
\hline 2015 & 17195550 & 5 & 85977750 & 295686939802500 & 25 \\
\hline$\Sigma$ & 193542511,000 & 102,000 & 1300066384,000 & 2537715969918710,000 & 712,180 \\
\hline Averages & 12902834,067 & 6,800 & 86671092,267 & 169181064661247,000 & 47,479 \\
\hline
\end{tabular}

Source: Own processing

Formulas, in the methodological part, are used to calculate the parameters for determining the correlation coefficient.

$\operatorname{cov} x y=3342744821839,13$

$\operatorname{var} \mathrm{x}=2697937709313,25 \quad \operatorname{var} \mathrm{y}=1,24$

The correlation coefficient:

$r=-0,6$

$\mathrm{R}^{2}=34,13 \%$

With a correlation coefficient of -0.6 , we can say that if the value of the correlation coefficient is closer to -1, it means that the dependence between the selected data is stronger but indirect. In our case it is a slight linear independence. The increasing number of guests affects the average unemployment rate of $39.34 \%$.

After obtaining these values, we calculated the parameters of the regression line, and then we fit them to the regression equation for the years 2001 and 2015.

The parameters of the regression are:

$\mathrm{b}=-0,000000396$

$\mathrm{a}=11,90854692$

The line equation is:

$\mathrm{y}(2001)=-0,17230630$

$y(2015)=-0,293887164$ 
The equation of the regression line is shown in Figure 3 and presents a slight indirect linear dependence. In this case, the growth of occupancy in the collective accommodation establishments in the Czech Republic in the period 2001 - 2015 leads to a reduction in the average unemployment rate, especially between 2005 - 2007 and 2014 - 2015.

Figure 3: The average rate of unemployment (\%) in total attendance at collective accommodation establishments in the Czech Republic during the period 2001-2015

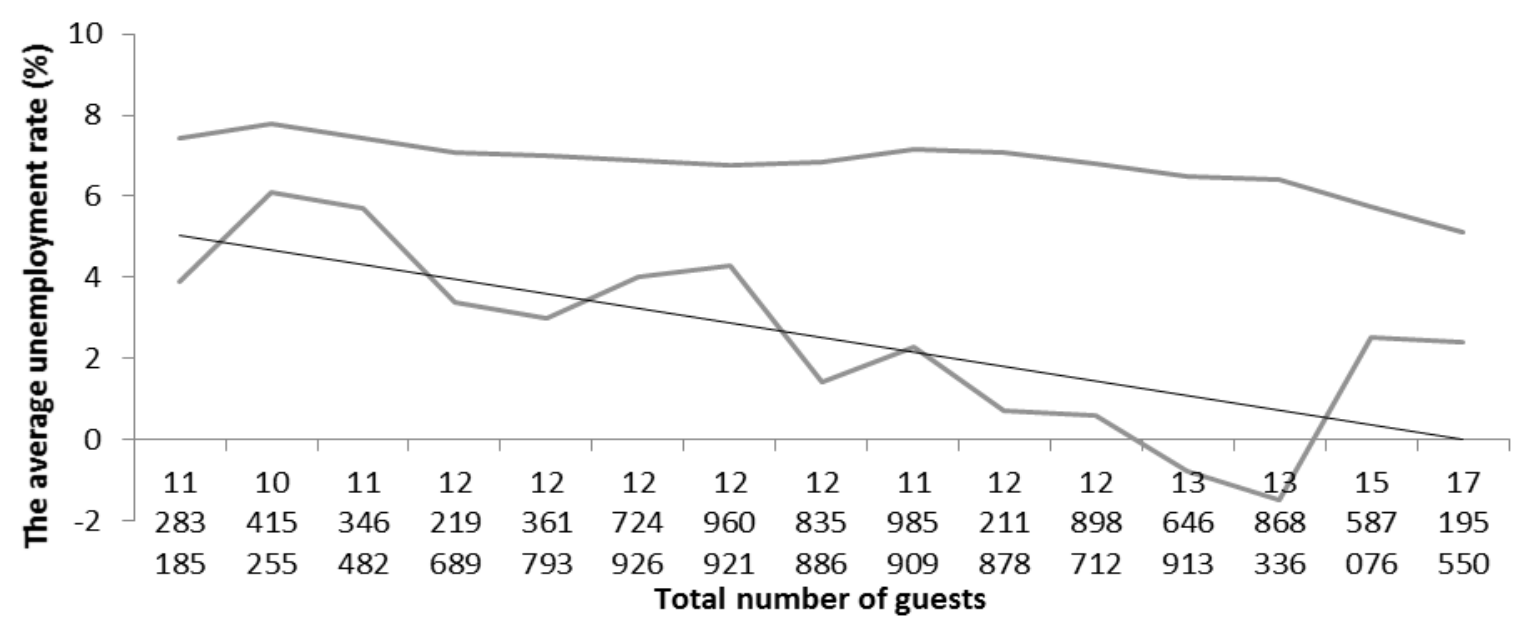

Source: Own processing

In the Correlation Table 2, authors examine the dependence of the GDP development (\%) in total attendance at collective accommodation establishments in the Czech Republic during the period 2001-2015.

Table 2: Dependence of development GDP (\%) in total attendance at collective accommodation establishments in the Czech Republic during the period 2001-2015

\begin{tabular}{|l|l|l|l|l|l|}
\hline Year & $\begin{array}{l}\text { (xi) } \\
\text { Number of guests } \\
\text { total }\end{array}$ & $\left(\mathbf{y}_{\mathbf{i}}\right) \mathbf{G D P}(\boldsymbol{\%})$ & $\mathbf{X i} * \mathbf{Y i}$ & $\mathbf{X i 2}$ & $\mathbf{Y i 2}$ \\
\hline $\mathbf{2 0 0 1}$ & 11283185 & 3,1 & 34977873,5 & 127310263744225 & 9,61 \\
\hline $\mathbf{2 0 0 2}$ & 10415255 & 1,6 & 16664408 & 108477536715025 & 2,56 \\
\hline $\mathbf{2 0 0 3}$ & 11346482 & 3,6 & 40847335,2 & 128742653776324 & 12,96 \\
\hline $\mathbf{2 0 0 4}$ & 12219689 & 4,9 & 59876476,1 & 149320799256721 & 24,01 \\
\hline $\mathbf{2 0 0 5}$ & 12361793 & 6,4 & 79115475,2 & 152813926174849 & 40,96 \\
\hline $\mathbf{2 0 0 6}$ & 12724926 & 6,9 & 87801989,4 & 161923741705476 & 47,61 \\
\hline $\mathbf{2 0 0 7}$ & 12960921 & 5,5 & 71285065,5 & 167985473168241 & 30,25 \\
\hline $\mathbf{2 0 0 8}$ & 12835886 & 2,7 & 34656892,2 & 164759969404996 & 7,29 \\
\hline $\mathbf{2 0 0 9}$ & 11985909 & $-4,8$ & $-57532363,2$ & 143662014556281 & 23,04 \\
\hline $\mathbf{2 0 1 0}$ & 12211878 & 2,3 & 28087319,4 & 149129964286884 & 5,29 \\
\hline $\mathbf{2 0 1 1}$ & 12898712 & 2,0 & 25797424 & 166376771258944 & 4 \\
\hline $\mathbf{2 0 1 2}$ & 13646913 & $-0,8$ & $-10917530,4$ & 186238234429569 & 0,64 \\
\hline $\mathbf{2 0 1 3}$ & 13868336 & $-0,5$ & -6934168 & 192330743408896 & 0,25 \\
\hline $\mathbf{2 0 1 4}$ & 15587076 & 2,7 & 42085105,2 & 242956938229776 & 7,29 \\
\hline $\mathbf{2 0 1 5}$ & 17195550 & 4,5 & 77379975 & 295686939802500 & 20,25 \\
\hline $\mathbf{\Sigma}$ & 193542511,000 & 40,100 & 523191277,100 & 2537715969918710,000 & 236,010 \\
\hline Averages & 12902834,067 & 2,673 & 34879418,473 & 169181064661247,000 & 15,734 \\
\hline SOurce: & & & & \\
\hline
\end{tabular}

Source: Own processing 
Formulas, in the methodological part, areused to calculate the parameters for determining the correlation coefficient.

$\operatorname{cov} x y=385842,0684$

$\operatorname{var} \mathrm{x}=2697937709313,25 \quad \operatorname{var} \mathrm{y}=8,59$

The correlation coefficient:

$\mathrm{r}=0,1$

$\mathrm{R}^{2}=64,26 \%$

With a correlation coefficient of 0.1 , we can say that if the correlation coefficient is around 0 , it means that the dependence between the selected variables is almost none.

By obtaining these values, we calculated the parameters of the regression line, and then we fit them to the regression equation for the years 2001 and 2015.

The parameters of the regression are as:

$\mathrm{b}=0,000000143$

$\mathrm{a}=0,827717892$

The line equation is:

$\mathrm{y}(2001)=0,06223956$

$\mathrm{y}(2015)=0,106156356$

The regression equation is illustrated in Figure 4 and it shows the dependence of the development of the GDP (\%) in total attendance at collective accommodation establishments in the Czech Republic during the period $2001-2015$

Figure 4: Dependence of the GDP development (\%) in total attendance at collective accommodation establishments in the Czech Republic during the period 2001-2015

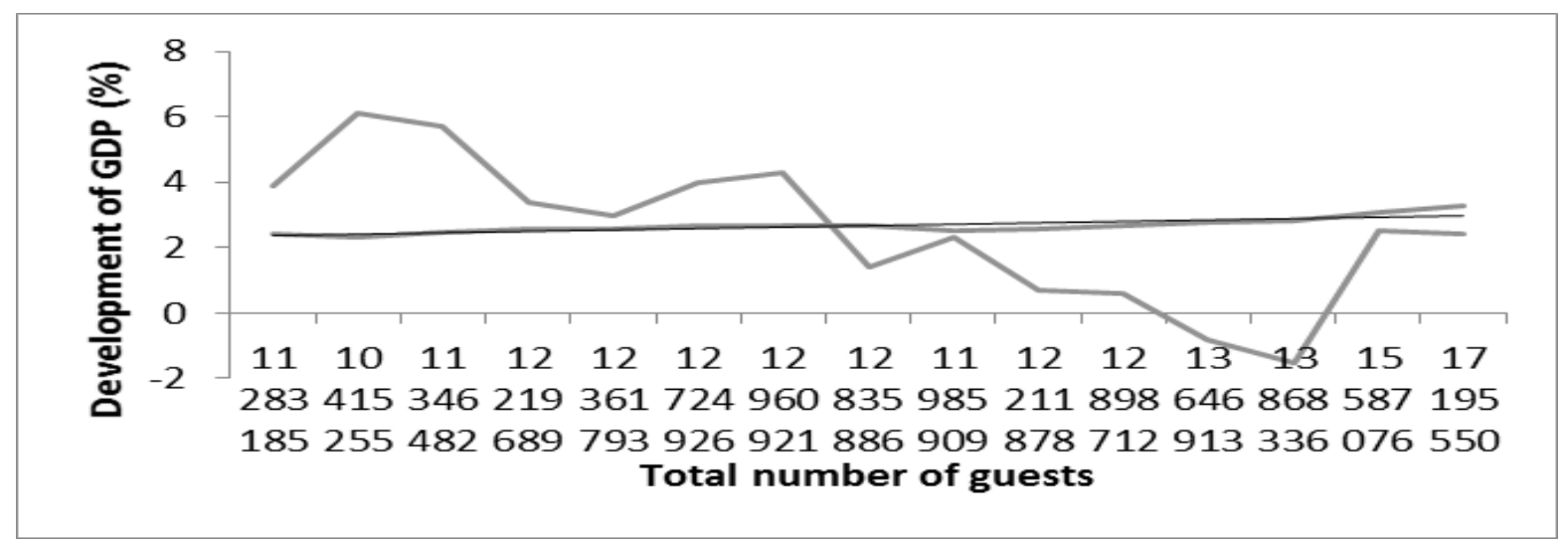

Source: Own processing

Correlation Table 3 shows the values for the period 2001-2015 and attendance time at the annual average real wage growth $(\%)$ and calculated parameters. The authors examine the dependence of the real wage growth $(\%)$ for total attendance at collective accommodation establishments in the Czech Republic during the period 2001 - 2015. 
Table 3: The evolution of the average pace of the real wage growth (\%) for total attendance at collective accommodation establishments in the Czech Republic during the period 2001-2015

\begin{tabular}{|l|l|l|l|l|l|}
\hline Year & $\begin{array}{l}\text { (xi) } \\
\text { Number of } \\
\text { guests } \\
\text { total }\end{array}$ & $\begin{array}{l}\text { (yi) O the } \\
\text { growth rate of } \\
\text { real wages (\%) }\end{array}$ & $\mathbf{X i} * \mathbf{Y i}$ & Xi2 & Yi2 \\
\hline $\mathbf{2 0 0 1}$ & 11283185 & 3,9 & 44004421,5 & 127310263744225 & 15,21 \\
\hline $\mathbf{2 0 0 2}$ & 10415255 & 6,1 & 63533055,5 & 108477536715025 & 37,21 \\
\hline $\mathbf{2 0 0 3}$ & 11346482 & 5,7 & 64674947,4 & 128742653776324 & 32,49 \\
\hline $\mathbf{2 0 0 4}$ & 12219689 & 3,4 & 41546942,6 & 149320799256721 & 11,56 \\
\hline $\mathbf{2 0 0 5}$ & 12361793 & 3 & 37085379 & 152813926174849 & 9 \\
\hline $\mathbf{2 0 0 6}$ & 12724926 & 4 & 50899704 & 161923741705476 & 16 \\
\hline $\mathbf{2 0 0 7}$ & 12960921 & 4,3 & 55731960,3 & 167985473168241 & 18,49 \\
\hline $\mathbf{2 0 0 8}$ & 12835886 & 1,4 & 17970240,4 & 164759969404996 & 1,96 \\
\hline $\mathbf{2 0 0 9}$ & 11985909 & 2,3 & 27567590,7 & 143662014556281 & 5,29 \\
\hline $\mathbf{2 0 1 0}$ & 12211878 & 0,7 & 8548314,6 & 149129964286884 & 0,49 \\
\hline $\mathbf{2 0 1 1}$ & 12898712 & 0,6 & 7739227,2 & 166376771258944 & 0,36 \\
\hline $\mathbf{2 0 1 2}$ & 13646913 & $-0,8$ & $-10917530,4$ & 186238234429569 & 0,64 \\
\hline $\mathbf{2 0 1 3}$ & 13868336 & $-1,5$ & -20802504 & 192330743408896 & 2,25 \\
\hline $\mathbf{2 0 1 4}$ & 15587076 & 2,5 & 38967690 & 242956938229776 & 6,25 \\
\hline $\mathbf{2 0 1 5}$ & 17195550 & 2,4 & 41269320 & 295686939802500 & 5,76 \\
\hline $\mathbf{\Sigma}$ & 193542511,000 & 38,000 & 467818758,800 & 2537715969918710,000 & 162,960 \\
\hline Averages & 12902834,067 & 2,533 & 31187917,253 & 169181064661247,000 & 10,864 \\
\hline
\end{tabular}

Source: Own processing

Formulas, in the methodological part, are used to calculate the parameters for determining the correlation coefficient.

$\operatorname{cov} \mathrm{xy}=12041165790436,00$

$\operatorname{var} \mathrm{x}=2697937709313,25 \quad$ var $\mathrm{y}=4,46$

The correlation coefficient:

$r=-0,4$

$\mathrm{R}^{2}=18,67 \%$

With a correlation coefficient of -0.4 , there is a weak indirect linear dependence. In this case, increasing the number of guests influenced the development of the average pace of the real wage growth $(\%)$ of $18,67 \%$.

By obtaining these values, we calculated the parameters of the regression line, and then we fit them to the regression equation for the years 2001 and 2015.

The parameters of the regression are:

$\mathrm{b}=-0,000000556$

$\mathrm{a}=9,703192875$

The parameters of the regression are:

$\mathrm{y}(2001)=-0,24184361$

$\mathrm{y}(2015)=-0,412490613$ 
The regression equation is illustrated in Figure 5 and shows the dependence of the development of an average pace of the real wage growth (\%) for total attendance at collective accommodation establishments in the Czech Republic during the period 2001 - 2015.

Figure 5: Dependence of average development rate of the real wage growth $(\%)$ for total attendance at collective accommodation establishments in the Czech Republic during the period 2001-2015

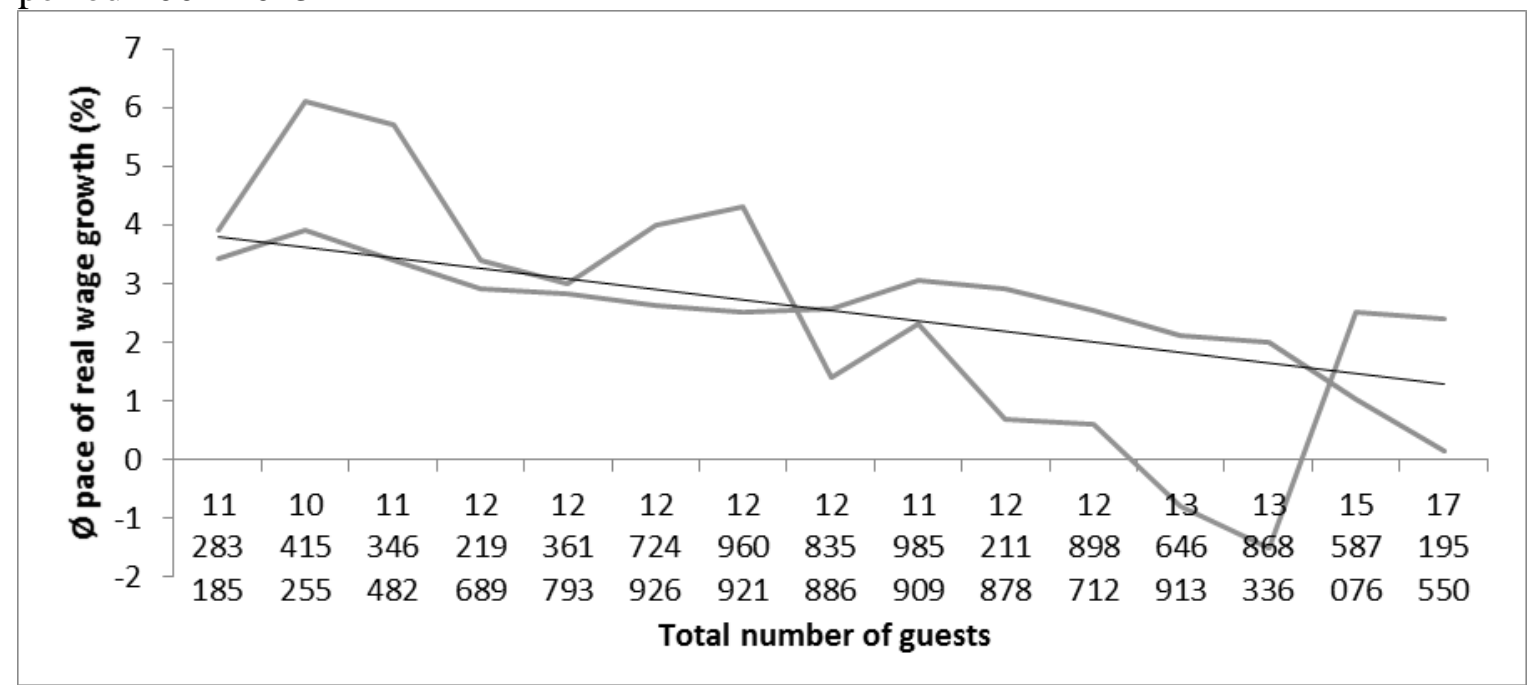

Source: Own processing

\section{Conclusion}

The Directive number 95/57 / EC (Council Directive) is applicable on the area of tourism statistics related to the collection of statistical information in the field of tourism (Appendix 7) in the European Union. On the basis of this Directive the EU member states are obliged to provide data on capacity and guests in collective accommodation establishments: domestic and outbound tourism in certain periodicity. The purpose of this article is to update the data. Indicators correspond to international methodology and are internationally comparable.

Tourism has become in recent decades an important economic activity with a positive impact on economic development and employment because of its development potential (multiplier effects).

The significance of the proportion of the gross domestic product from tourism activities in the overall global economic output roughly corresponds to other industrial sectors and, together with a financial system it can rank among the most productive service sector. This is an industry with long-term growth of jobs.

Tourism is an important sector, which provides employment opportunities and significantly affects other areas. It has an influence on the GDP, has a positive effect on the balance of payments, creates state budget revenues, affecting the income of local budgets and, ultimately, promotes investment activity.

The aim of this paper is to assess the impact of occupancy in collective accommodation establishments in the Czech Republic at an average rate of unemployment (\%) to GDP (\%) and the average pace of the real wage growth (\%) between 2001-2015. The first parameter is the influence of guests at collective accommodation establishments in the Czech Republic on an average rate of unemployment (\%). It was shown that the dependence between parameters 
is stronger but indirect. We can conclude that the increasing number of guests affects the average unemployment rate of $39.34 \%$. It means that the growth in occupancy of collective accommodation establishments reduces the average unemployment rate. It should be noted that jobs are affected by seasonality in tourism and this trend can be verified on the pages of the Czech Statistical Office, namely the Tourism Satellite Account.

Generally, tourism has a significant influence on supporting the development of small and medium-sized businesses, stimulates investments in the local infrastructure, increasing the general educational level and living standard of the population.

There has been demonstrated an indirect weak linear dependence. The influence cannot be considered significant.

However, tourism is also largely influenced by seasonality. It follows that attendance of collective accommodation establishments has an impact on selected economic indicators. Tourism is important for the economy and collective accommodation facilities are important to support the economy. In the future, the authors are going to continue to monitor the impact of the variables.

This paper was supported by the Ministry of Education, Youth and Sports Czech Republic within the Institutional Support for Long-term Development of a Research Organization in 2016.

\section{Literature}

[1] HINDLS, R., S. HRONOVÁ, J. SEGER and J. FISCHER, 2007.Statistika pro ekonomy. 8. Vyd. Praha:Professional Publishing. ISBN 978-80-86946-43-6.

[2] JAKUBÍKOVÁ, D. 2012. Marketing v cestovnich ruchu. Praha: Grada. ISBN 978-80247-4209-0.

[3] JASINSKAS, E., 2016. Impact of hotel service quality on the loyalty of costumers. Economic research-Ekonomska istrazivanja, 29 (1), 559-572. ISSN 1331-677X.

[4] KOStKOVÁ, M., X. LUKOSZOVÁ and M. WILCZKOVÁ, 2009. Analysis of tourism supply in Czech Republic. In: Zeszyty naukowe Katedry nauk ekonomicznych WSEiA Bytom. Bytom: WSEiA. s. 239-244. ISSN 1642-980X.

[5] LAMONICA, J. R. and E. MATTIOLI, 2015. The impact of the tourism industry on the world's largest economies - an input-output analysis. In: Tourism management, 21 (2), 419-426, DOI: 10.5367/te.2013.0363.

[6] Mc CLAVE, J. and T. SINCICH. 2011 Statistics, 12th edition, Pearson Education Ltd. ISBN 978-1-292-02265-9.

[7] MORRISON, A. M., 1995. Marketing pohostinství a cestovního ruchu. 1. vyd. Praha: Victoria Publishing, ISBN 80-85605-90-2.

[8] PELLEŠOVÁ, P. 2015. Tourism and multiplication effents in the region. In: Innovation managament and sustainable economic competitive advantage: from regional development to global drowth, volsi - VI. Madrid: Int Business Informat Managament Assoc, s. 515-520. ISBN 978-0-9860419-5-2-

[9] PERLES-RIBES, J. S., A. B. RAMON-RODRÍGUES, M. SEVILLA-JIMENEZ and L. MORENO-IZQUIERDO, 2016. Unemployment effects of economic crises on hotel and 
residential tourism destinations: The case of Spain. In: Tourism management, 54, p. 356368, DOI: 10.1016/j.tourman.2015.12.002.

[10] RAM, R. and S. URAL, 2014. Comparison of GDP Per Capita Data in Penn World Table and World Development Indicators. In: Social indicators research, 116 (2), 639-646, DOI: $10.1007 / \mathrm{s} 11205-013-0284-0$.

[11] RAMÍK, J. and R. STOKLASOVÁ. 2013. Statistické zpracování dat. Karviná: SU OPF. ISBN 978-80-7248-842-1.

[12] ŠAMBORSKÁ, K., D. MATUŠÍKOVÁ, A. ŠENKOVÁ and J. MITRÍKOVÁ, 2016. Comparison of tourism performance in chosen european countries with the accent to Slovak republic in the period before and after accession to European union membership at the beginning of 21 th century. In: Ecoforum, 1 (8), 107-114.

[13] TOŠENOVSKÝ, F. 2014. Statistické metody pro ekonomy. Karviná: SU OPF. ISBN 97880-7510-031-3.

[14] VÁCLAVÍNKOVÁ, K., 2012. Možnosti podpory venkovského cestovního ruchu v oblasti Moravskoslezské Beskydy. Acta academica karviniensia, 7 (2). 147-158. ISSN 1212-415-X.

[15] VÁGNER, J., 2011. Vývoj cestovního ruchu. [Online] [vid. February 14, 2017]. Available from: http://geography.cz/geograficke-rozhledy/wpcontent/uploads/2011/10/4-5.pdf

[16] Web portal of the Czech Statistical Office: Tourism - time series. [Online] [vid. September 29, 2016]. Available from: https://www.czso.cz/csu/czso/cru_cr

[17] Web portal of the Czech Statistical Office: The main macroeconomic indicators. [Online] [vid. September 29, 2016]. Available from: https://www.czso.cz/csu/czso/hmu_cr 